\title{
Preparation of Palladium-Impregnated Ceria by Metal Complex Decomposition for Methane Steam Reforming Catalysis
}

\author{
Worawat Wattanathana, ${ }^{1}$ Suttipong Wannapaiboon, ${ }^{2,3}$ Chatchai Veranitisagul, ${ }^{4}$ \\ Navadol Laosiripojana, ${ }^{5}$ Nattamon Koonsaeng, ${ }^{6}$ and Apirat Laobuthee ${ }^{1}$ \\ ${ }^{1}$ Department of Materials Engineering, Faculty of Engineering, Kasetsart University, Chatuchak, Bangkok 10900, Thailand \\ ${ }^{2}$ Synchrotron Light Research Institute, 111 University Avenue, Suranaree, Muang, Nakhon Ratchasima 30000, Thailand \\ ${ }^{3}$ Chair of Inorganic and Metal-Organic Chemistry, Technical University of Munich, Lichtenbergstr. 4, 85748 Garching, Germany \\ ${ }^{4}$ Department of Materials and Metallurgical Engineering, Faculty of Engineering, \\ Rajamangala University of Technology Thanyaburi, Klong 6, Thanyaburi, Pathumthani 12110, Thailand \\ ${ }^{5}$ The Joint Graduate School of Energy and Environment, CHE Center for Energy Technology and Environment, \\ King Mongkut's University of Technology Thonburi, Bangkok 10140, Thailand \\ ${ }^{6}$ Department of Chemistry, Faculty of Science, Kasetsart University, Chatuchak, Bangkok 10900, Thailand
}

Correspondence should be addressed to Apirat Laobuthee; fengapl@ku.ac.th

Received 15 May 2017; Accepted 16 August 2017; Published 3 October 2017

Academic Editor: Andres Sotelo

Copyright (C) 2017 Worawat Wattanathana et al. This is an open access article distributed under the Creative Commons Attribution License, which permits unrestricted use, distribution, and reproduction in any medium, provided the original work is properly cited.

Palladium-impregnated ceria materials were successfully prepared via an integrated procedure between a metal complex decomposition method and a microwave-assisted wetness impregnation. Firstly, ceria $\left(\mathrm{CeO}_{2}\right)$ powders were synthesized by thermal decomposition of cerium(III) complexes prepared by using cerium(III) nitrate or cerium(III) chloride as a metal source to form a metal complex precursor with triethanolamine or benzoxazine dimer as an organic ligand. Palladium(II) nitrate was consequently introduced to the preformed ceria materials using wetness impregnation while applying microwave irradiation to assist dispersion of the dopant. The palladium-impregnated ceria materials were obtained by calcination under reduced atmosphere of $10 \% \mathrm{H}_{2}$ in He stream at $700^{\circ} \mathrm{C}$ for $2 \mathrm{~h}$. Characterization of the palladium-impregnated ceria materials reveals the influences of the metal complex precursors on the properties of the obtained materials. Interestingly, the palladium-impregnated ceria prepared from the cerium(III)-benzoxazine dimer complex revealed significantly higher BET specific surface area and higher content of the more active $\operatorname{Pd}^{\delta+}(\delta>2)$ species than the materials prepared from cerium(III)-triethanolamine complexes. Consequently, it exhibited the most efficient catalytic activity in the methane steam reforming reaction. By optimization of the metal complex precursors, characteristics of the obtained palladium-impregnated ceria catalysts can be modified and hence influence the catalytic activity.

\section{Introduction}

Cerium oxide or so-called ceria $\left(\mathrm{CeO}_{2}\right)$ naturally contains a high concentration of mobile oxygen vacancy sites, which are created by replacement of a fraction of the $\mathrm{Ce}^{4+}$ occupancies within the ceria lattice by trivalent cerium ions $\left(\mathrm{Ce}^{3+}\right)[1]$. These self-generated oxygen vacancy sites act as local sources or sinks for oxygen which take part in the reactions occurring at its surface and therefore enhance the interest in using ceria for a wide range of catalytic applications [2-9]. One of the promising applications of ceria is the use as catalyst support, of which desired characteristics reveal significant influences on the impregnation process of such active catalytic species (e.g,. metal nanoparticles and metal oxide additives), catalytic activity, and stability of the embedded catalysts [10]. Hence, optimizing the preparation procedure of the catalytic support is crucial in order to achieve an effective performance of catalysts.

Among various synthetic procedures, thermal decomposition of metal complexes is one of the useful techniques for synthesizing ceramic materials. This method provides many advantages, that is, simple and straightforward procedure, 
low cost, high availability, and variability of complex formations with miscellaneous cations. Success is highlighted by our achievements within the past decades for preparations of various metal oxides by the thermal decomposition of metal-triethanolamine complexes [11-17]. In particular, ceria and rare-earth-doped ceria materials have been successfully prepared and examined for the applications as solid support catalysts [18-22] and solid electrolytes in solid oxide fuel cells $[23,24]$.

Apart from using cerium(III)-triethanolamine complexes as starting precursors for the thermal decomposition process, the alternative choices of chelating ligands have been investigated. Recently, the use of benzoxazine dimer derivatives as ligand for metal complex precursors has revealed a promising choice for synthesizing ceria through thermal decomposition of metal complex [25]. Therefore, in this work, we extend the state of the art toward the study of the influences of precursor choices used for the metal complex formations on characteristics of the obtained ceria materials and consequently on the catalytic activity after impregnation of palladium catalysts onto the ceria solid support. Specifically, three different combinations of metal sources and organic ligands have been used to prepare metal complex precursors, namely, (a) cerium(III) nitrate hexahydrate $\left(\mathrm{Ce}\left(\mathrm{NO}_{3}\right)_{3} \cdot 6 \mathrm{H}_{2} \mathrm{O}\right)$ and triethanolamine ligand, (b) cerium(III) chloride heptahydrate $\left(\mathrm{CeCl}_{3} \cdot 7 \mathrm{H}_{2} \mathrm{O}\right)$ and triethanolamine ligand, and (c) cerium(III) nitrate hexahydrate and benzoxazine dimer, $N, N$ bis(5-methoxy-2-hydroxybenzyl) methyl amine (MeMD), of which the structure was reported previously [25]. Note that the metal complex precursor prepared by combining cerium(III) chloride heptahydrate and benzoxazine dimer MeMD ligand is excluded from this study due to the less stability of this metal complex.

Methane steam reforming is selected to be the proofof-concept reaction for a catalytic activity test. Unlike the conventional homogeneous combustion of methane (known as one of the most powerful greenhouse gases) at high temperature which normally emits $\mathrm{CO}$ and $\mathrm{NO}_{x}$ as products [26], this reaction provides a useful outcome by conversion of methane to the more valuable fuel, hydrogen gas. Pdbased materials have been well known as an example of the most active catalysts for hydrogen production from natural gases such as by methane steam reformation and partial oxidation. However, the catalytic activity is not stable when directly used in the reactions. Therefore, impregnation and embedding of the Pd-based catalysts in metal oxide support are required to increase the activity and stability of the active Pd-based catalysts [10, 27]. Herein, an attempt to investigate the influences of different precursors used for preparation of ceria materials by thermal decomposition of metal complexes on the function as the catalytic support materials has been accomplished. Palladium catalyst is introduced onto the ceria solid support by employing microwave-assisted wetness impregnation of palladium(II) nitrate dihydrate with the different molar ratios. Calcination under reduced atmosphere was used to generate the catalyticactive palladium-impregnated ceria materials prior to the test of catalytic activity, which is examined by the percentages of methane conversion.

\section{Experimental}

2.1. Chemicals. Cerium(III) nitrate hexahydrate $\left(\mathrm{Ce}\left(\mathrm{NO}_{3}\right)_{3}\right.$. $\left.6 \mathrm{H}_{2} \mathrm{O}\right)$ and cerium(III) chloride heptahydrate $\left(\mathrm{CeCl}_{3} \cdot 7 \mathrm{H}_{2} \mathrm{O}\right)$ were supplied from Acros Organics. Palladium(II) nitrate dihydrate $\left(\mathrm{Pd}\left(\mathrm{NO}_{3}\right)_{2} \cdot 2 \mathrm{H}_{2} \mathrm{O}\right)$ was purchased from SigmaAldrich, while triethanolamine (TEA, $\mathrm{N}\left(\mathrm{CH}_{2} \mathrm{CH}_{2} \mathrm{OH}\right)_{3}$ ) was obtained from CARLO ERBA Reagents. Solvents (ethanol and 1-propanol) were bought from Merck. All chemicals were used without further purification.

\subsection{Preparation of Cerium Complexes and Ceria. Prepara-} tion of cerium-triethanolamine complexes was carried out by the same procedure as our previous literatures $[19,22]$. The cerium salt (cerium(III) nitrate hexahydrate or cerium(III) chloride heptahydrate, $150 \mathrm{mmol}$ ) was dissolved in 1-propan$\mathrm{ol}$ in a round bottom flask. The equimolar amount of triethanolamine was then added to the solution of the cerium salt. The mixture was distilled for $5 \mathrm{~h}$ to eliminate water, a byproduct from complexation, and 1-propanol solvent. After the reaction completed, pale-yellow precipitates of the complexes were formed. The precipitates were dried using rotary evaporator.

One of the derivatives of benzoxazine dimers, so-called MeMD, was used as a ligand to form complex with cerium(III) nitrate. Hereinafter, we call the ligand "benzoxazine dimer." Cerium(III) nitrate hexahydrate and the benzoxazine dimer with the molar ratio of $1: 6$ were mixed together in ethanol in order to form cerium-benzoxazine dimer complex [25]. The complexation occurred very rapidly, since there was an immediate color change to dark purple after mixing two colorless substances together. The solution was heated and stirred for $30 \mathrm{~min}$ to ensure complete reaction.

All the obtained complexes were used as precursors for synthesizing ceria powders. According to the thermogravimetric analyses in the previous works $[19,22,25]$, the calcination temperature was selected to be $600^{\circ} \mathrm{C}$. Therefore, all the prepared cerium complexes were subjected to calcination at $600^{\circ} \mathrm{C}$ for $2 \mathrm{~h}$ under air atmosphere to turn into ceria powders via thermal decomposition. The ceria powders obtained after the heat treatment of the complexes were pale-yellow colored.

\subsection{Preparation of Palladium-Impregnated Ceria Catalysts.}

The prepared ceria powders were intended to be used as catalyst support for palladium. The method used for introducing palladium onto the surface of ceria powders was microwave-assisted wetness impregnation, where the ceria support was soaked with palladium salt solution. Prior to impregnation, the obtained ceria powders were ground using mortar and pestle and then sieved with the size of $45 \mu \mathrm{m}$. Palladium(II) nitrate dihydrate with $1 \%$ and $3 \%$ by mole was dissolved in deionized water and then added to the prepared ceria. The mixtures were sonicated for $30 \mathrm{~min}$ and then heated with domestic microwave to help palladium particles distribute evenly on the surface of the ceria support. After that, the impregnated samples were calcined under $10 \% \mathrm{H}_{2}$ / $\mathrm{He}$ atmosphere at $700^{\circ} \mathrm{C}$ for $2 \mathrm{~h}$. 

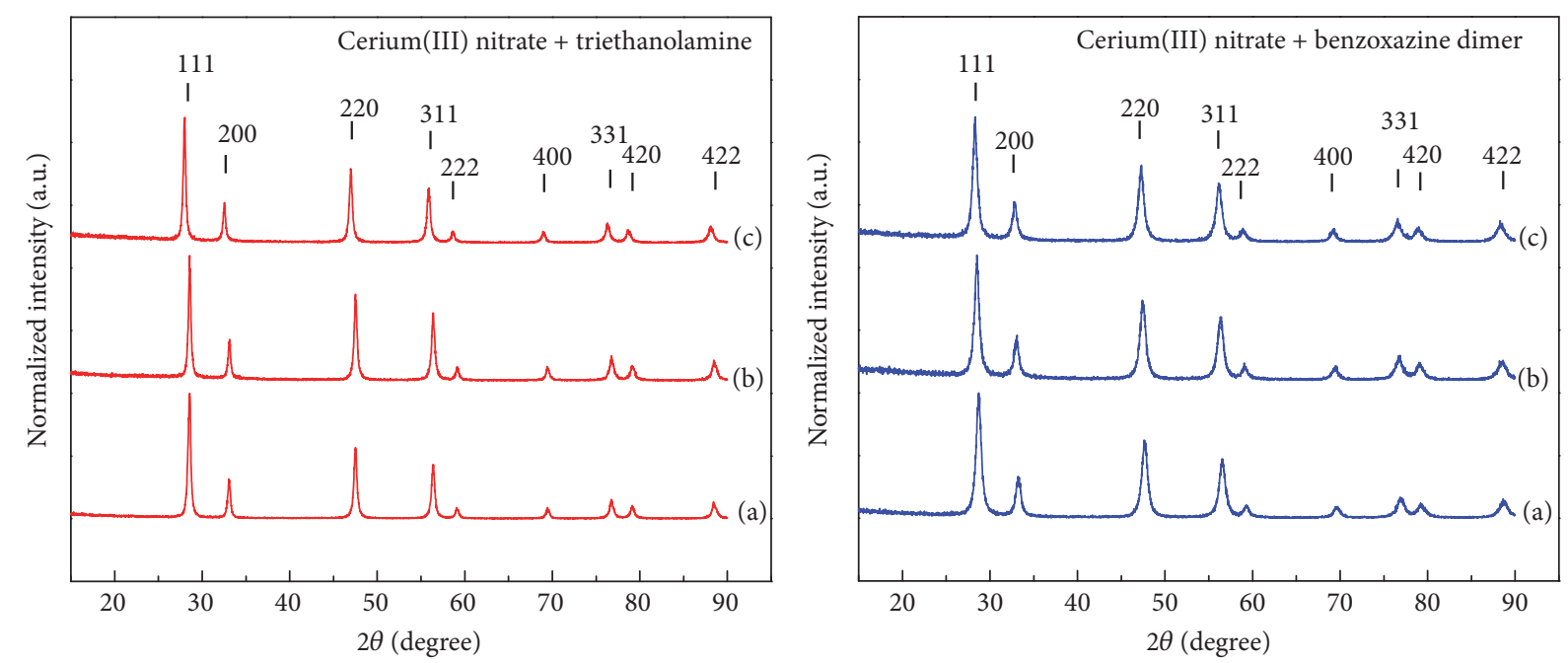

FIGURE 1: XRD patterns of the obtained products of (a) ceria after the thermal decomposition of the metal complex at $600^{\circ} \mathrm{C}$ for $2 \mathrm{~h}$, further used as a catalytic support; (b) ceria support after microwave-assisted wetness impregnation of palladium(II) nitrate (3\% mole); (c) Pdimpregnated ceria catalyst after calcination under reduced atmosphere of $10 \% \mathrm{H}_{2}$ in $\mathrm{He}$ stream at $700^{\circ} \mathrm{C}$ for $2 \mathrm{~h}$, denoted as $3 \mathrm{Pd}-\mathrm{CeO} 2-\mathrm{T}-\mathrm{N}$ (red curves) and 3Pd-CeO2-B-N (blue curves) with regard to the use of cerium(III) nitrate to prepare metal complexes with triethanolamine and benzoxazine dimer ligand, respectively.

2.4. Materials Characterization. X-ray diffraction (XRD) analysis was carried out at room temperature on the prepared catalysts using an X-ray diffractometer (X'Pert PRO MPD diffractometer) operating at $40 \mathrm{kV}$ and $30 \mathrm{~mA}$ using nickelfiltered $\mathrm{Cu} \mathrm{K} \alpha$ radiation. Diffraction patterns were recorded in the $2 \theta$ range of $20-90^{\circ}$ by step scanning with a step interval of $0.02^{\circ}$ and a scanning time of $2 \mathrm{~s}$ for each step. The crystallite size $\left(D_{\mathrm{XRD}}\right)$ of the calcined powders was determined using the Scherrer equation: $D=0.9 \lambda / \beta \cos \theta$, where $\lambda$ is the wavelength of the X-rays (1.5406 $\AA$ ), $\theta$ is the scattering angle of the main reflection (111), and $\beta$ is the corrected peak at full width at half maximum (FWHM) intensity. Morphology of the prepared catalysts was studied by scanning electron microscope (SEM, JEOL JSM5410) equipped with an energy dispersive X-ray analyzer (EDX). Prior to the study, the samples were mounted on stubs using carbon tape and then sputtered with $\mathrm{Au}$ to avoid particle charging. Moreover, transmission electron microscope (TEM, JEOL JEM-2100) equipped with an EDX unit was used for further investigation of microstructure of the materials. X-ray photoelectron spectroscopy (XPS) was operated to investigate the elemental species and their oxidation states in the obtained materials. The specific surface area $\left(S_{\mathrm{BET}}\right)$ of the obtained catalysts was measured from nitrogen adsorption isotherm at $77 \mathrm{~K}$ using a surface area analyzer (Micromeritics) based on the Brunauer-Emmett-Teller (BET) principle. The mesopore size distribution was further analyzed based on the BarrettJoyner-Halenda (BJH) method.

2.5. Study on Catalytic Activity toward Methane Steam Reforming. Conversion of methane steam reforming reaction was studied in a temperature-programmed microflow reactor operated at ambient pressure. A catalyst with approximately
$50 \mathrm{mg}$ was packed in the quartz tube in the reactor. Reagent gases were flowed in the tube containing the catalyst with a flow rate in the range from 20 to $200 \mathrm{~cm}^{3} \mathrm{~min}^{-1}$. After the reactions, the exit gas mixture was transferred via traceheated lines $\left(100^{\circ} \mathrm{C}\right)$ to the analysis section, which consists of a Porapak Q column, Shimadzu 14B gas chromatograph (GC). The outlet of the GC column was directly connected to thermal conductivity detector (TCD) and flame ionization detector (FID). In order to satisfactorily separate all elements, the temperature setting inside the GC column was programmed varying with time. In the first $3 \mathrm{~min}$, the column temperature was constant at $60^{\circ} \mathrm{C}$; it was then increased steadily by the rate of $15^{\circ} \mathrm{C} \mathrm{min}{ }^{-1}$ until $120^{\circ} \mathrm{C}$ and lastly decreased to $60^{\circ} \mathrm{C}$.

\section{Results and Discussion}

Ceria powders were synthesized by thermal decomposition at $600^{\circ} \mathrm{C}$ for $2 \mathrm{~h}$ of three different cerium(III) complexes formed by using different precursor sources as follows: (a) cerium(III) chloride heptahydrate as a metal source and triethanolamine as a ligand (coined as $\mathrm{CeO} 2-\mathrm{T}-\mathrm{Cl}$ ), (b) cerium(III) nitrate hexahydrate and triethanolamine ligand (CeO2-T-N), and (c) cerium(III) nitrate hexahydrate and benzoxazine dimer derivative ligand $(\mathrm{CeO} 2-\mathrm{B}-\mathrm{N})$. Note that structural characteristics of the three metal complex precursors have been thoroughly investigated and reported in our previous works $[22,25]$ and are not discussed further in this recent work. The obtained ceria powders exhibit high crystallinity indexed to be the face-centered cubic $\mathrm{CeO}_{2}$ (JCPDS number 34-0394) and no crystalline impurity is observed in the XRD patterns (as demonstrated in Figure 1(a) in both red and blue curves). 
TABLE 1: Crystallite size calculated by Scherrer equation according to the XRD patterns, percentage of different chemical states of the Pd-based species according to the Pd $3 \mathrm{~d}$ XPS spectra, and specific surface area derived from BET calculation of $\mathrm{N}_{2}$ adsorption isotherm at $77 \mathrm{~K}\left(S_{\mathrm{BET}}\right)$ of the obtained Pd-impregnated ceria catalysts.

\begin{tabular}{|c|c|c|c|c|c|}
\hline \multirow{2}{*}{$\begin{array}{l}\text { Pd-impregnated } \\
\text { ceria catalysts }\end{array}$} & \multirow{2}{*}{$\begin{array}{l}\text { FWHM } \\
\text { (degree) }\end{array}$} & \multirow{2}{*}{ Crystallite size $(\mathrm{nm})$} & \multicolumn{2}{|c|}{$\%$ of Pd-based species } & \multirow{2}{*}{$\begin{array}{c}S_{\mathrm{BET}} \\
\left(\mathrm{m}^{2} / \mathrm{g}\right)\end{array}$} \\
\hline & & & $\mathrm{Pd}^{2+}$ & $\operatorname{Pd}^{\delta+}(\delta>2)$ & \\
\hline 1Pd-CeO2-T-Cl & 0.28328 & 30.20 & - & - & 17.22 \\
\hline 3Pd-CeO2-T-Cl & 0.28363 & 30.16 & 76.6 & 23.4 & 17.70 \\
\hline 1Pd-CeO2-T-N & 0.49834 & 17.17 & - & - & 14.30 \\
\hline 3Pd-CeO2-T-N & 0.39466 & 21.68 & 75.7 & 24.3 & 11.42 \\
\hline $1 \mathrm{Pd}-\mathrm{CeO} 2-\mathrm{B}-\mathrm{N}$ & 0.77191 & 11.10 & - & - & 62.89 \\
\hline 3Pd-CeO2-B-N & 0.70906 & 12.07 & 70.0 & 30.0 & 57.01 \\
\hline
\end{tabular}

These obtained ceria powders were further used as catalytic support to impregnate palladium catalyst by using microwave-assisted wetness impregnation of palladium(II) nitrate dihydrate for $1 \%$ and $3 \%$ mole. For notation of the synthesized Pd-impregnated ceria catalysts reported herein, we coin the term $\mathbf{x P d - C e O 2 - a - b}$, where $\mathbf{x}$ denotes percentages of Pd impregnating amount ( $\mathbf{1}$ for $1 \%$ and $\mathbf{3}$ for $3 \%$ mole), a denotes type of organic ligand used for preparation of metal complex ( $\mathbf{T}$ for triethanolamine and $\mathbf{B}$ for benzoxazine dimer), and $\mathbf{b}$ denotes type of cerium salts used for preparation of metal complex ( $\mathbf{C l}$ for cerium(III) chloride and $\mathbf{N}$ for cerium(III) nitrate). The materials were characterized by $\mathrm{XRD}$ after the wetness impregnation process, and there is no significant change of the XRD patterns (or crystallinity) of the ceria support before and after the impregnation (Figure 1(b)). In order to activate the Pd-impregnated ceria catalyst, the materials were further treated by calcination at $700^{\circ} \mathrm{C}$ for $2 \mathrm{~h}$ under reduced atmosphere of $10 \% \mathrm{H}_{2}$ in $\mathrm{He}$ stream. XRD patterns of the obtained Pd-impregnated ceria catalysts show no significant change from the crystallinity of the ceria support materials before impregnation (Figure 1(c)). Moreover, there are no additional diffraction peaks related to crystalline Pd-based materials, indicating the rather small particles as well as the lack of long-range crystallite ordering of the Pd-based species in the materials.

With closer inspection on the XRD patterns of the Pdimpregnated ceria catalysts derived from different metal complex precursors (Figure 2), it is noteworthy that a variation of metal complex precursors influences the crystallinity of the obtained materials. Specifically, crystallinity of ceria support is highest when using cerium(III) chloride and triethanolamine for preparing metal complex precursor (Figure 2, black curves), followed by the cases of using cerium(III) nitrate and triethanolamine (Figure 2, red curves), and the lowest crystallinity is in the cases of using cerium(III) nitrate and benzoxazine dimer (Figure 2, blue curves). Crystallite sizes calculated by Scherrer equation according to the XRD patterns are shown in Table 1, highlighting dependence on the metal complex precursors. The use of benzoxazine dimer as ligand for cerium complex formation notably reduces the crystallite size of the ceria product.

Scanning electron microscopic (SEM) images of the six different $\mathrm{Pd}$-impregnated ceria catalysts are illustrated in

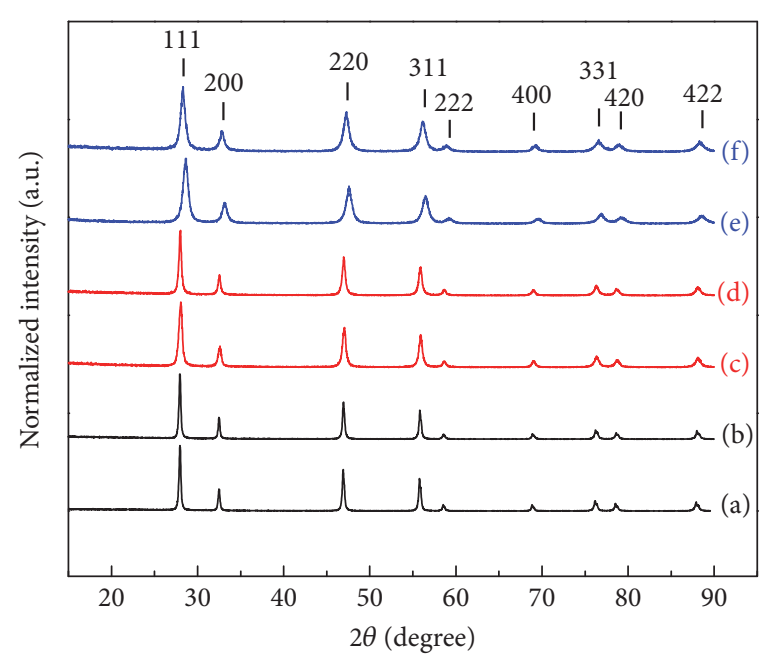

FIGURE 2: Comparison of XRD patterns of the Pd-impregnated ceria catalysts prepared by using ceria support derived from different metal complex precursors and impregnating Pd with two different concentrations: (a) 1Pd-CeO2-T-Cl, (b) 3Pd-CeO2-T-Cl, (c) 1PdCeO2-T-N, (d) 3Pd-CeO2-T-N, (e) 1Pd-CeO2-B-N, and (f) 3Pd$\mathrm{CeO} 2-\mathrm{B}-\mathrm{N}$.

Figure 3. According to the overview of SEM images, the Pdimpregnated ceria materials are observed as aggregation of nanometer-sized particles, which cannot easily distinguish the influences of the different metal complex precursors and the impregnating concentrations on the particle size and morphology. However, the corresponding energy dispersive X-ray (EDX) spectrum and the EDX elemental mapping (shown in Figure 4 as an example) indicate that cerium, oxygen, and palladium are well distributed within the material matrix. This evidence reveals preliminary success of impregnation of Pd-based catalysts onto the ceria support.

To get insight into microstructures of the Pd-impregnated ceria catalysts, TEM is further used for microscopic characterization. According to the TEM images (Figure 5), the effect of different metal complex precursors on the particle size of Pd-impregnated ceria catalysts is clearly observed. Specifically, Pd-impregnated ceria prepared by cerium(III)benzoxazine dimer complex shows significantly smaller particle size (approximately $10 \mathrm{~nm}$ ) than the ones prepared 


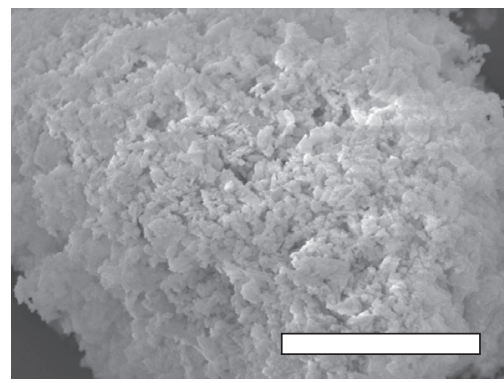

(a)

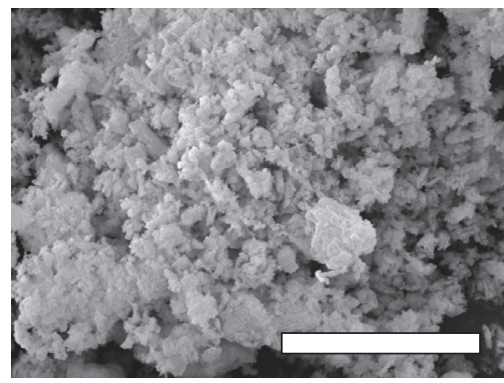

(b)

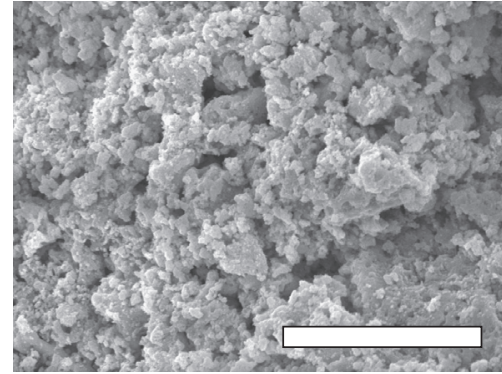

(c)

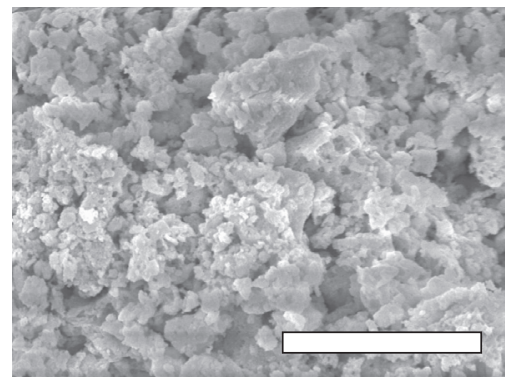

(d)

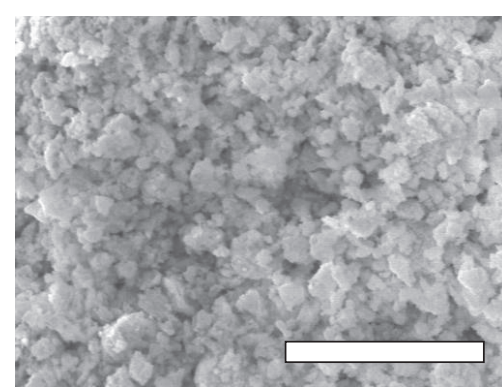

(e)

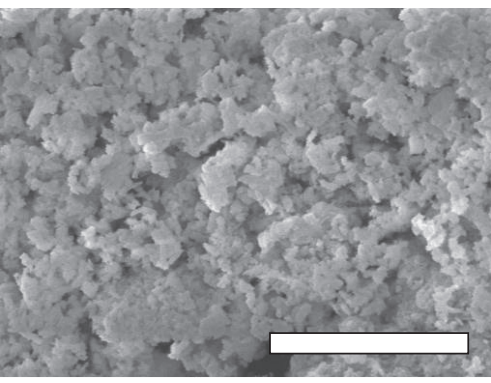

(f)

Figure 3: SEM images of the Pd-impregnated ceria catalysts. (a) 1Pd-CeO2-T-Cl, (b) 3Pd-CeO2-T-Cl, (c) 1Pd-CeO2-T-N, (d) 3Pd-CeO2-T-N, (e) $1 \mathrm{Pd}-\mathrm{CeO} 2-\mathrm{B}-\mathrm{N}$, and (f) $3 \mathrm{Pd}-\mathrm{CeO} 2-\mathrm{B}-\mathrm{N}$. Scale bar represents $10 \mu \mathrm{m}$.
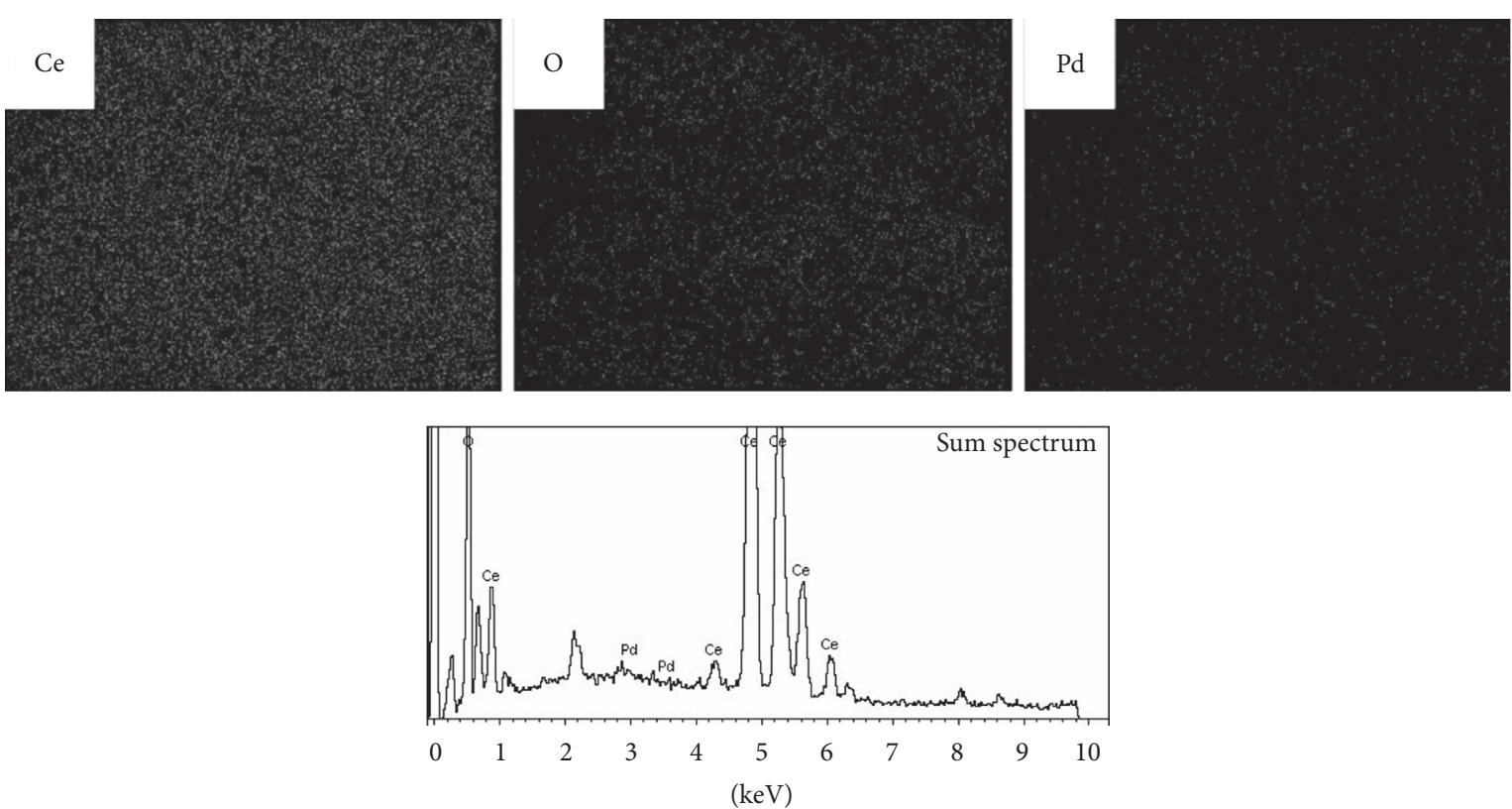

Full scale 569 cts cursor: -0.092 ( 0 cts)

FIGURE 4: EDX mapping of cerium, oxygen, and palladium within $1 \mathrm{Pd}-\mathrm{CeO} 2-\mathrm{B}-\mathrm{N}$ showing a good distribution of the three elements within the material matrix and its corresponding EDX spectrum based on SEM image.

from cerium(III)-triethanolamine complexes. High-resolution TEM image of the 3Pd-CeO2-B-N catalyst (Figure 5(d)) clearly indicates the crystallite planes (111) and (200) of $\mathrm{CeO}_{2}$ with the crystallite plane size of 0.319 and $0.285 \mathrm{~nm}$, respectively. Note that it is rather complicated to distinguish presence of Pd-based species by TEM due to a low content of Pd doping amount. However, EDX spectrum (Figure 5(e)) indicates the presence of Pd-based species with a better signal of Pd content than the EDX spectra observed in the bulk materials according to SEM measurements (Figure 4).

To clearly elucidate the presence of Pd species impregnated in the materials, XPS spectra of the Pd-impregnated 


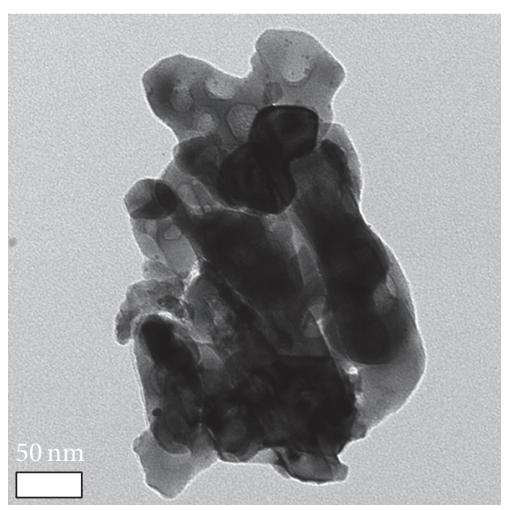

(a)

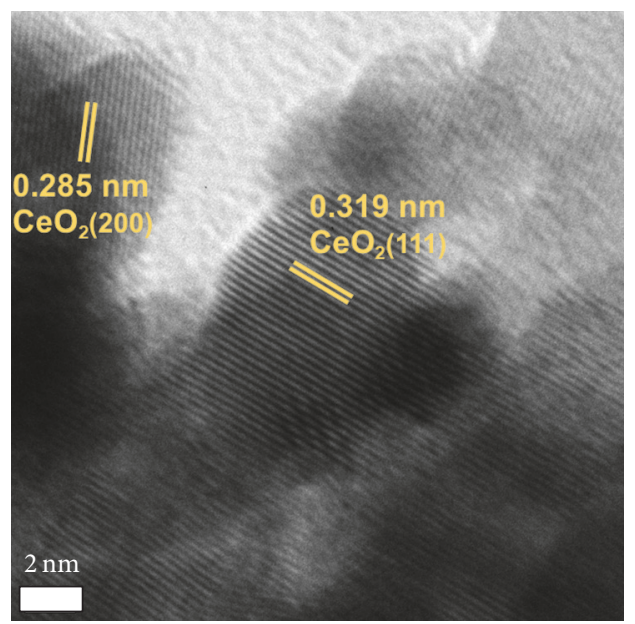

(d)

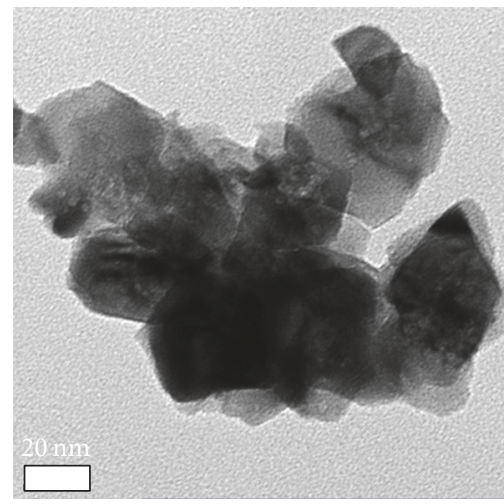

(b)

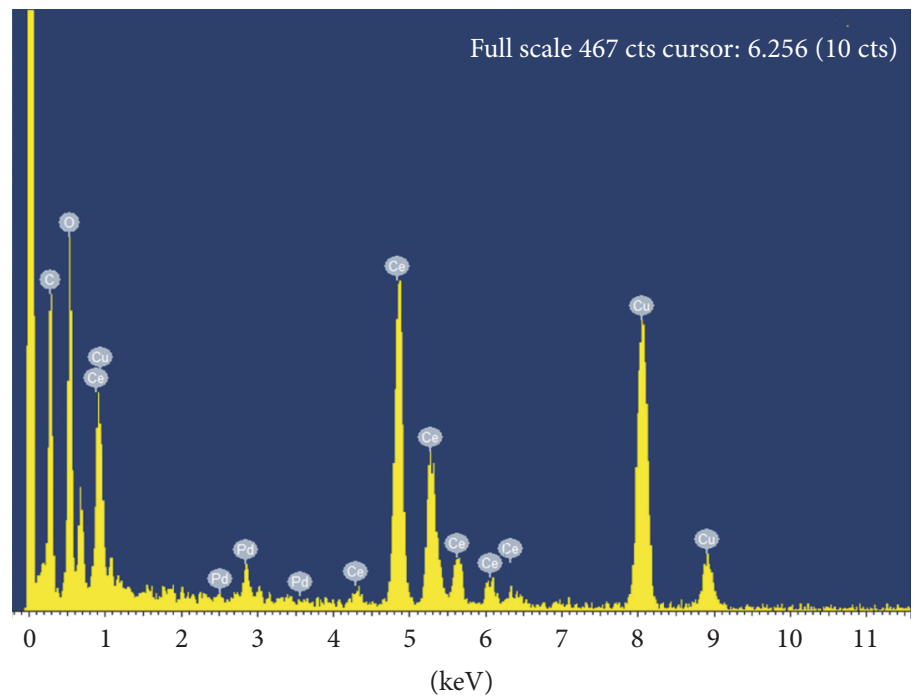

(e)

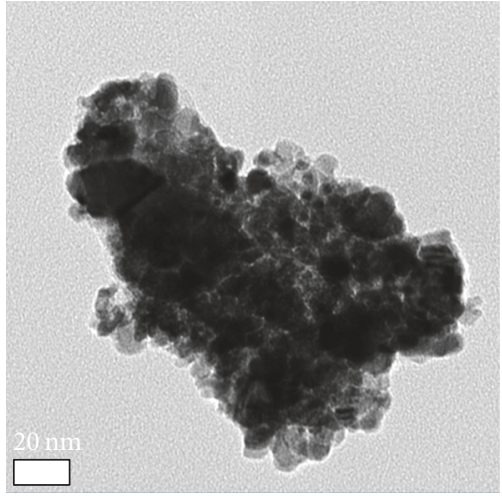

(c)

Figure 5: TEM images of the Pd-impregnated ceria catalysts. (a) 3Pd-CeO2-T-Cl, (b) 3Pd-CeO2-T-N, and (c) 3Pd-CeO2-B-N. (d) Highresolution TEM image of the $3 \mathrm{Pd}-\mathrm{CeO} 2-\mathrm{B}-\mathrm{N}$ catalyst indicating the crystallite planes of $\mathrm{CeO}_{2} ;(\mathrm{e})$ the corresponding EDX spectrum of the $3 \mathrm{Pd}-\mathrm{CeO} 2-\mathrm{B}-\mathrm{N}$ catalyst based on TEM image in (c).

ceria catalysts are recorded (Figure 6). The XPS results of Pd $3 \mathrm{~d}_{5 / 2}$ could be decomposed into two components at a binding energy of 337.0 and $339.0 \mathrm{eV}$, which could be assigned to oxidized $\mathrm{Pd}$ species of $\mathrm{Pd}^{2+}$ and $\mathrm{Pd}^{\delta+}(\delta>2)$, respectively. Moreover, the XPS results of $\mathrm{Pd} 3 \mathrm{~d}_{3 / 2}$ could be also decomposed into two components of oxidized Pd species of $\mathrm{Pd}^{2+}$ and $\mathrm{Pd}^{\delta+}(\delta>2)$. Interestingly, the Pd-impregnated ceria prepared by cerium(III)-benzoxazine dimer complex exhibits the highest content of the high-oxidative $\mathrm{Pd}^{\delta+}(30.0 \%$, see Table 1). Herein, we confirm successful impregnation of oxidized Pd-based catalyst on the $\mathrm{CeO}_{2}$ support.

Specific surface area $\left(S_{\mathrm{BET}}\right.$ in Table 1$)$ of the obtained Pdimpregnated ceria catalysts is derived from BET calculation of $\mathrm{N}_{2}$ adsorption isotherm at $77 \mathrm{~K}$ (Figures 7(a) and 7(b)). The results clearly indicate that the use of benzoxazine dimer ligand leads to the formation of ceria materials with observably higher specific surface area (approximately $60 \mathrm{~m}^{2} / \mathrm{g}$ ) than 


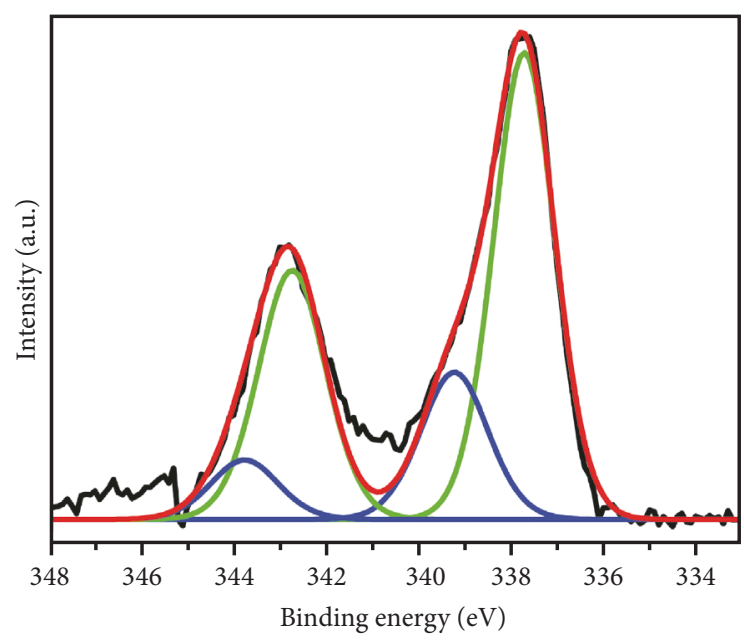

(a)

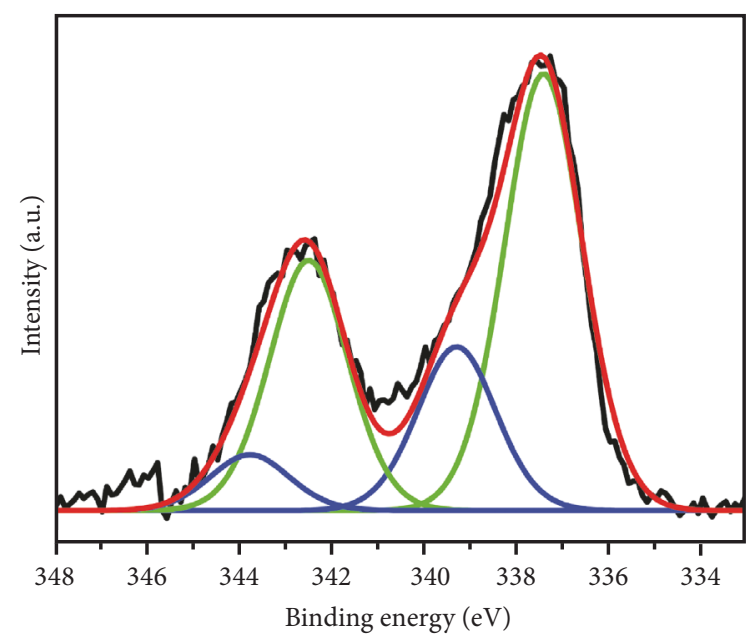

(b)

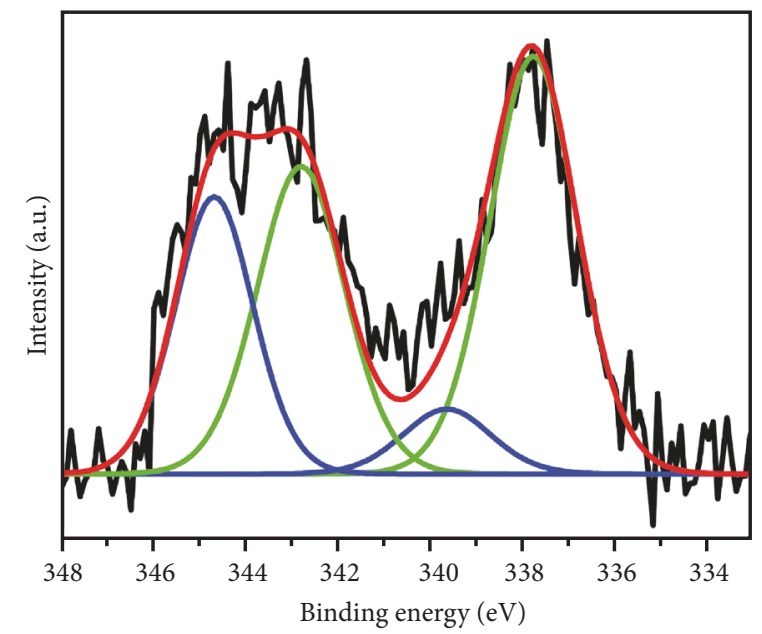

(c)

Figure 6: Pd 3d XPS profiles of the Pd-impregnated ceria catalysts. (a) 3Pd-CeO2-T-Cl, (b) 3Pd-CeO2-T-N, and (c) 3Pd-CeO2-B-N. The green and blue lines represent the decomposed spectra which could be assigned to the oxidized Pd species of $\operatorname{Pd}^{2+}$ and $\mathrm{Pd}^{\delta+}(\delta>2)$, respectively. The red line represents the combination of all decomposed spectra of Pd 3d.

the materials synthesized from cerium(III)-triethanolamine complexes, highlighting the influence of precursor choices on the characteristics of the obtained materials.

Catalytic activity of the Pd-impregnated ceria catalysts prepared by using ceria support derived from different metal complex precursors was tested in the methane steam reforming reaction operated at ambient pressure in a microflow reactor. Percentages of methane conversion as a function of reaction time using each $\mathrm{Pd}$-impregnated ceria catalyst are shown in Figure 8. In each precursor type, it is clearly observed that the higher amount of Pd particles impregnated onto the ceria support is, the higher catalytic reactivity for the conversion of methane steam reforming is (the $3 \% \mathrm{Pd}$ impregnation shows higher reactivity than the $1 \% \mathrm{Pd}$ case with respect to the same metal complex precursors). Interestingly, a difference of catalytic activity as dependence of the metal complex precursors is notably observed. The use of Pd-impregnated ceria catalysts derived from the use of
cerium(III) nitrate-benzoxazine dimer complex (blue curves) shows the highest percentage of methane conversion of $75 \%$ after $1 \mathrm{~h}$ of reaction time, whereas the catalytic reactivity is gradually increased as a function of reaction time when using the Pd-impregnated ceria catalysts derived from the cerium(III) chloride-triethanolamine complex precursors (black curves), reaching $70 \%$ conversion after $8 \mathrm{~h}$ reaction time.

Referring to the XPS spectra and BET surface area analysis, the Pd-impregnated ceria catalysts derived from the use of cerium(III) nitrate-benzoxazine dimer complex contain higher amount of $\operatorname{Pd}^{\delta+}(\delta>2)$ species and higher BET surface area than the other cases. The $\mathrm{Pd}^{\delta+}$ species reveal that more electrons transfer to the oxide support and are more oxidatively active than the metallic $\mathrm{Pd}$ and the $\mathrm{Pd}^{2+}$ species [28-32]. The higher oxidation state $\mathrm{Pd}^{\delta+}$ should accelerate the $\mathrm{C}-\mathrm{H}$ bond activation of the $\mathrm{CH}_{4}$ molecule on the coordinatively unsaturated (CUS) Pd and consequently enhances the 


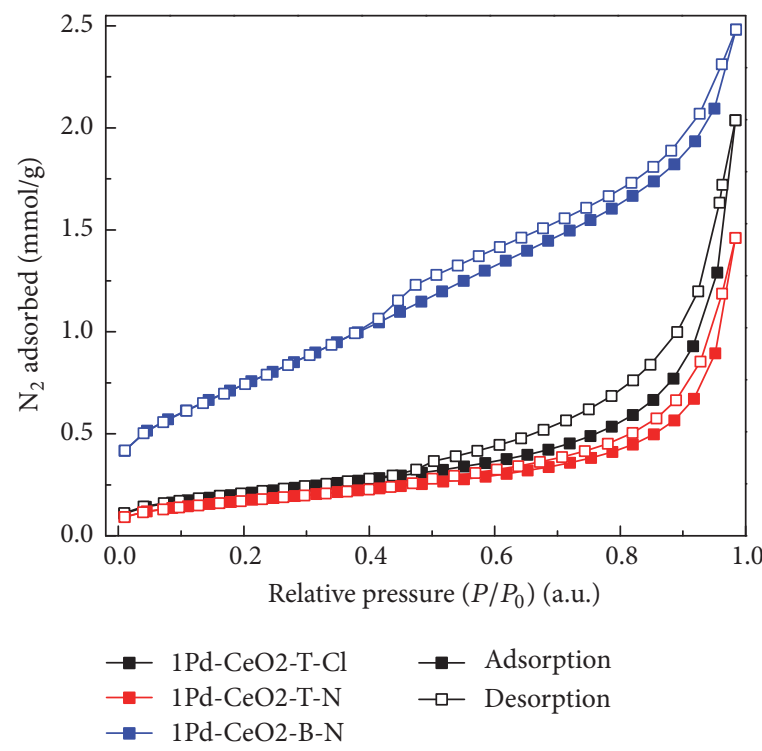

(a)

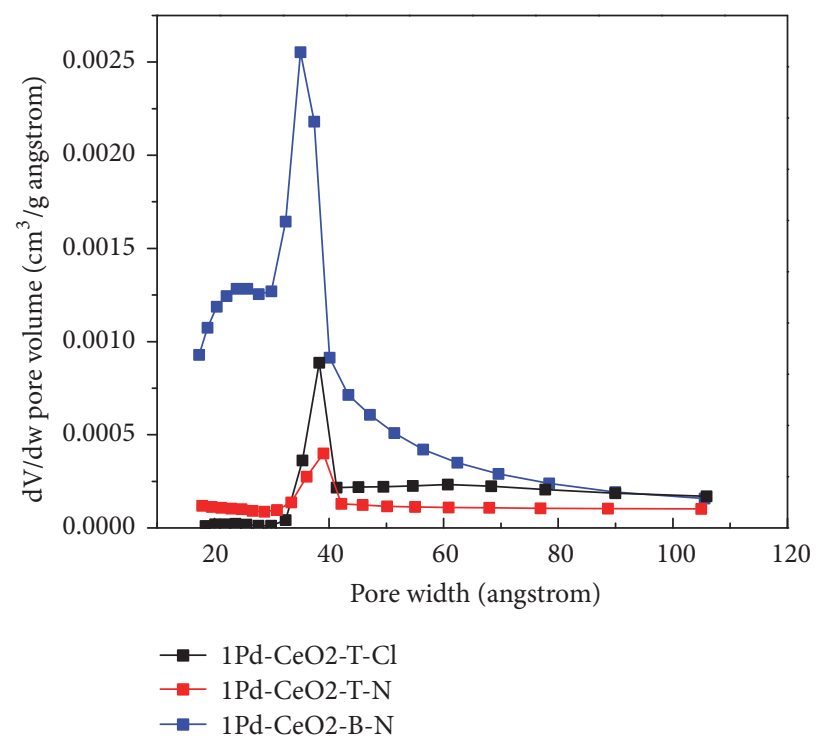

(c)

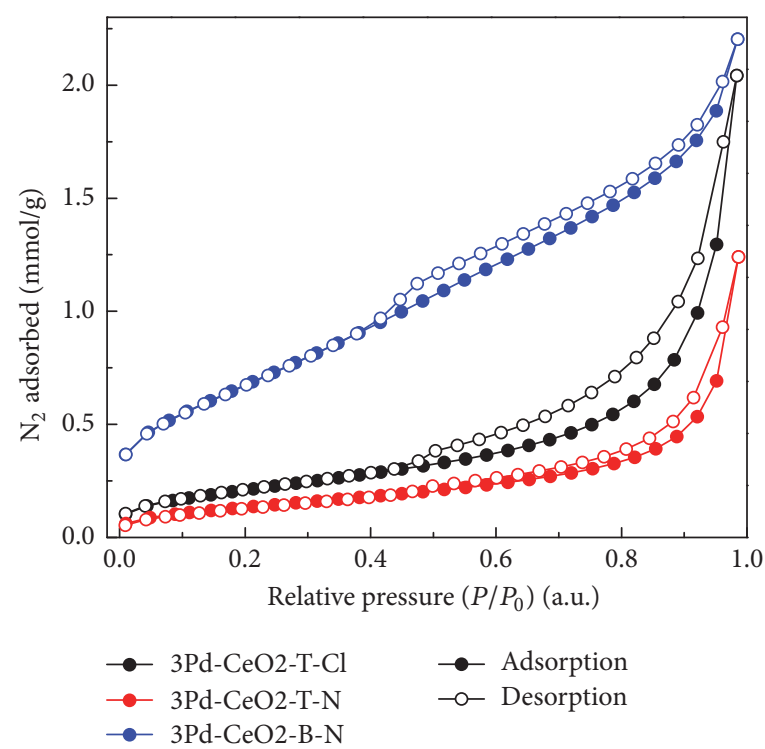

(b)

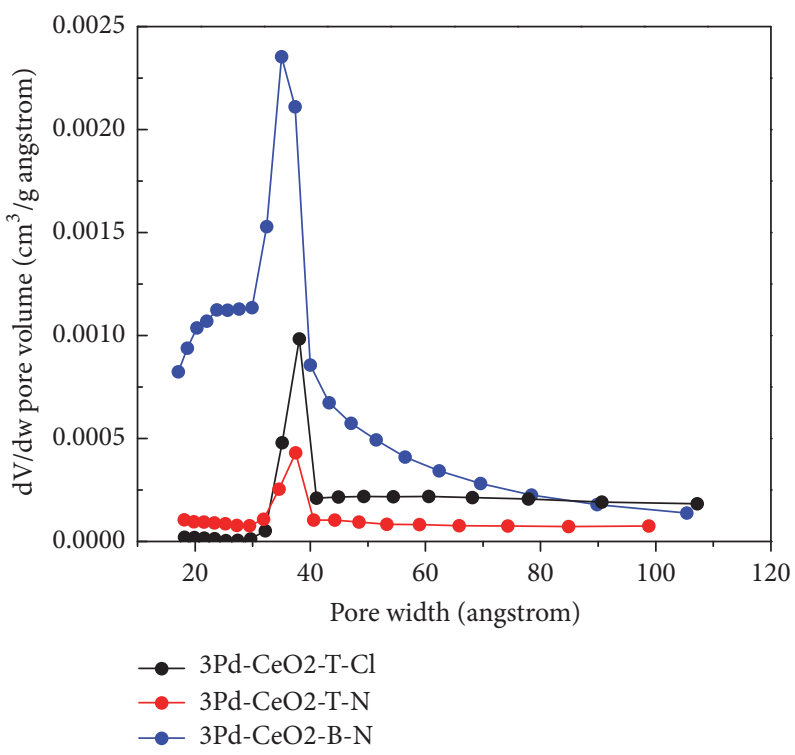

(d)

Figure 7: Nitrogen adsorption isotherms at $77 \mathrm{~K}$ of the (a) $1 \%$ and (b) $3 \%$ Pd-impregnated ceria catalysts; ((c) and (d)) their corresponding pore size distribution based on $\mathrm{BJH}$ method of the $1 \%$ and $3 \% \mathrm{Pd}$-impregnated ceria catalysts, respectively.

catalytic activity [31,32]. Hence, it reveals a consequence of the higher catalytic activity of the Pd-impregnated ceria by means of the higher BET specific surface area and the higher content of the more active $\mathrm{Pd}^{\delta+}(\delta>2)$ species, which can be modified by the choice of metal complex precursors used for synthesis of the ceria support by the thermal decomposition method.

\section{Conclusions}

Characteristics of ceria support materials are strongly influenced by the choice of metal complex precursors used for the thermal decomposition process. Optimizing the metal complex precursors leads to a systematic control of particles sizes and consequently specific surface area of the obtained ceria support. The higher surface area of ceria support, achieved by the use of cerium(III)-benzoxazine dimer complex as the thermal decomposition precursor, enhances the quality of impregnation of the catalytically active Pd-based species onto the ceria support. Moreover, the higher content of the more active $\operatorname{Pd}^{\delta+}(\delta>2)$ species within the Pd-impregnated ceria catalysts derived from the cerium(III)-benzoxazine dimer complex creates a higher catalytic performance for the methane steam reforming reaction. By optimization of the 


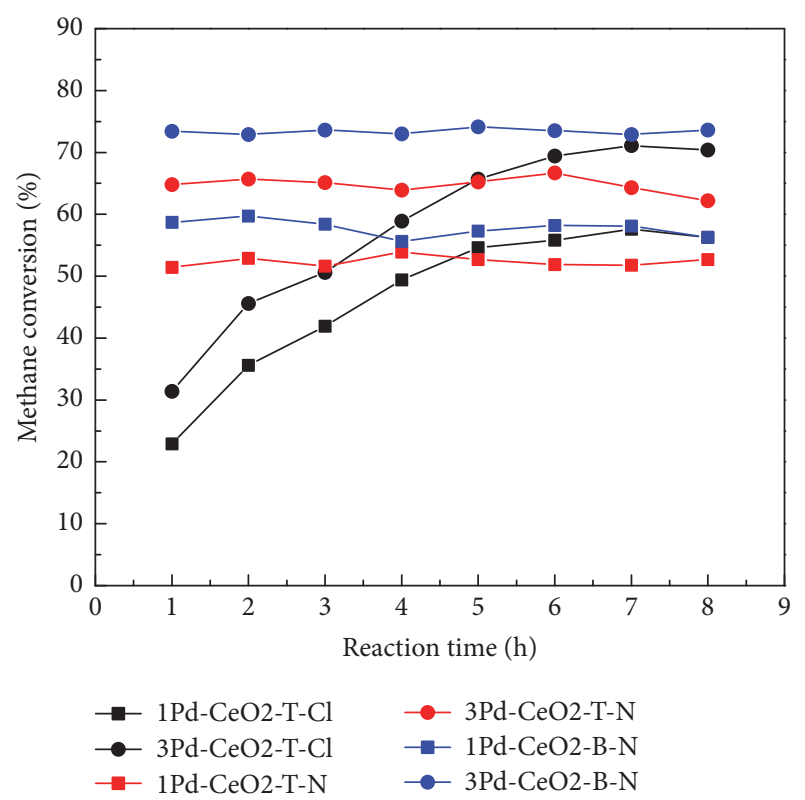

FIgURE 8: Catalytic activity of the obtained Pd-impregnated ceria catalysts according to percentages of methane conversion during the methane steam reforming reaction for hydrogen gas production.

metal complex precursors, characteristics and catalytic activity of the obtained Pd-impregnated ceria catalysts can be diligently modified and enhanced.

\section{Conflicts of Interest}

The authors declare that there are no conflicts of interest regarding the publication of this paper.

\section{Acknowledgments}

This work was supported by Kasetsart University Research and Development Institute (KURDI); Department of Chemistry, Faculty of Science, Kasetsart University; Department of Materials Engineering, Faculty of Engineering, Kasetsart University; and the Development and Promotion of Science and Technology Talents Project (DPST).

\section{References}

[1] K. C. Anjaneya, J. Manjanna, G. P. Nayaka, V. M. Ashwin Kumar, G. Govindaraj, and K. N. Ganesha, "Citrate-complexation synthesized $\mathrm{Ce}_{0.85} \mathrm{Gd}_{0.15} \mathrm{O}_{2-\delta}(\mathrm{GDC15})$ as solid electrolyte for intermediate temperature SOFC," Physica B: Condensed Matter, vol. 447, pp. 51-55, 2014.

[2] A. Trovarelli, "Catalytic properties of ceria and $\mathrm{CeO}_{2}$-containing materials," Catalysis Reviews-Science and Engineering, vol. 38, no. 4, pp. 439-520, 1996.

[3] P. Fornasiero, G. Balducci, R. Di Monte et al., "Modification of the redox behaviour of $\mathrm{CeO}_{2}$ induced by structural doping with $\mathrm{ZrO}_{2}$," Journal of Catalysis, vol. 164, no. 1, pp. 173-183, 1996.

[4] T. Miki, T. Ogawa, M. Haneda et al., "Enhanced oxygen storage capacity of cerium oxides in cerium dioxide/lanthanum sesquioxide/alumina containing precious metals," The Journal of Physical Chemistry, vol. 94, no. 16, pp. 6464-6467, 1990.

[5] C. Padeste, N. W. Cant, and D. L. Trimm, "The influence of water on the reduction and reoxidation of ceria," Catalysis Letters, vol. 18, no. 3, pp. 305-316, 1993.

[6] S. Kacimi, J. Barbier Jr., R. Taha, and D. Duperz, "Oxygen storage capacity of promoted $\mathrm{Rh} / \mathrm{CeC}_{2}$ catalysts. Exceptional behavior of $\mathrm{RhCu} / \mathrm{CeO}_{2}$," Catalysis Letters, vol. 22, no. 4, pp. 343-350, 1993

[7] G. S. Zafiris and R. J. Gorte, "Evidence for a second CO oxidation mechanism on Rh/Ceria," Journal of Catalysis, vol. 143, no. 1, pp. 86-91, 1993.

[8] G. S. Zafiris and R. J. Gorte, "Evidence for low-temperature oxygen migration from ceria to Rh," Journal of Catalysis, vol. 139, no. 2, pp. 561-567, 1993.

[9] S. Imamura, M. Shono, N. Okamoto, A. Hamada, and S. Ishida, "Effect of cerium on the mobility of oxygen on manganese oxides," Applied Catalysis A: General, vol. 142, no. 2, pp. 279288, 1996.

[10] M. Cargnello, J. J. Delgado Jaen, J. C. Hernandez Garrido et al., "Exceptional activity for methane combustion over modular $\mathrm{Pd} @ \mathrm{CeO}_{2}$ subunits on functionalized $\mathrm{Al}_{2} \mathrm{O}_{3}$," Science, vol. 337, no. 6095, pp. 713-717, 2012.

[11] A. Laobuthee, S. Wongkasemjit, E. Traversa, and R. M. Laine, " $\mathrm{MgAl}_{2} \mathrm{O}_{4}$ spinel powders from oxide one pot synthesis (OOPS) process for ceramic humidity sensors," Journal of the European Ceramic Society, vol. 20, no. 2, pp. 91-97, 2000.

[12] A. Laobuthee, N. Koonsaeng, B. Ksapabutr, M. Panapoy, and C. Veranitisagul, "Doped $\mathrm{MgAl}_{2} \mathrm{O}_{4}$ spinel screen print thick film as sensing material for humidity measurement," International Journal of Materials Structure Reliability, vol. 3, no. 2, pp. 95103, 2005.

[13] P. Hasin, N. Koonsaeng, and A. Laobuthee, "Nickel-aluminium complex: a simple and effective precursor for nickel aluminate $\left(\mathrm{NiAl}_{2} \mathrm{O}_{4}\right)$ spinel," Maejo International Journal of Science and Technology, vol. 2, no. 1, pp. 140-149, 2008.

[14] S. Ummartyotin, S. Sangngern, N. Koonsaeng, N. Yoswathananont, M. Sato, and A. Laobuthee, "Preliminary study of nickel aluminate prepared from nickel complex as a solid support for hydrogenation reaction in a continuous-flow microreactor," Journal of Research in Engineering and Technology, vol. 5, pp. 375-391, 2008.

[15] S. Ummartyotin, S. Sangngern, A. Kaewvilai, N. Koonsaeng, H. Manuspiya, and A. Laobuthee, "Cobalt aluminate $\left(\mathrm{CoAl}_{2} \mathrm{O}_{4}\right)$ derived from Co-Al-TEA complex and its dielectric behaviors," Journal of Sustainable Energy \& Environment, vol. 1, pp. 31-37, 2010.

[16] T. Thaweechai, A. Wisitsoraat, A. Laobuthee, and N. Koonsaeng, "Ethanol sensing of $\mathrm{La}_{1-\mathrm{x}} \mathrm{Sr}_{\mathrm{x}} \mathrm{FeO}_{3}(\mathrm{x}=0,0.1$, and 0.3 ) prepared by metal-organic complex decomposition," Kasetsart Journal- Natural Science, vol. 43, no. 5, pp. 218-223, 2009.

[17] W. Nantharak, W. Wattanathana, W. Klysubun et al., "Effect of local structure of $\mathrm{Sm}^{3+}$ in $\mathrm{MgAl}_{2} \mathrm{O}_{4}: \mathrm{Sm}^{3+}$ phosphors prepared by thermal decomposition of triethanolamine complexes on their luminescence property," Journal of Alloys and Compounds, vol. 701, pp. 1019-1026, 2017.

[18] A. Laobuthee, C. Veranitisagul, N. Koonsaeng, V. Bhavakul, and N. Laosiripojana, "Catalytic activity of ultrafine $\mathrm{Ce}_{x} \mathrm{Gd}_{y} \mathrm{Sm}_{z} \mathrm{O}_{2}$ synthesized by metal organic complex method toward steam reforming of methane," Catalysis Communications, vol. 12, no. 1, pp. 25-29, 2010. 
[19] W. Wattanathana, A. Lakkham, A. Kaewvilai, N. Koonsaeng, A. Laobuthee, and C. Veranitisagul, "Preliminary study of Pd/ $\mathrm{CeO}_{2}$ derived from cerium complexes as solid support catalysts for hydrogenation reaction in a micro-reactor," Energy Procedia, vol. 9, pp. 568-574, 2011.

[20] C. Veranitisagul, N. Koonsaeng, N. Laosiripojana, and A. Laobuthee, "Preparation of gadolinia doped ceria via metal complex decomposition method: Its application as catalyst for the steam reforming of ethane," Journal of Industrial and Engineering Chemistry, vol. 18, no. 3, pp. 898-903, 2012.

[21] A. Laobuthee, C. Veranitisagul, W. Wattanathana, N. Koonsaeng, and N. Laosiripojana, "Activity of Fe supported by $\mathrm{Ce}_{1-\mathrm{x}} \mathrm{Sm}_{\mathrm{x}} \mathrm{O}_{2-\delta}$ derived from metal complex decomposition toward the steam reforming of toluene as biomass tar model compound," Renewable Energy, vol. 74, pp. 133-138, 2015.

[22] W. Wattanathana, N. Nootsuwan, C. Veranitisagul, N. Koonsaeng, N. Laosiripojana, and A. Laobuthee, "Simple ceriumtriethanolamine complex: Synthesis, characterization, thermal decomposition and its application to prepare ceria support for platinum catalysts used in methane steam reforming," Journal of Molecular Structure, vol. 1089, pp. 9-15, 2015.

[23] C. Veranitisagul, A. Kaewvilai, W. Wattanathana, N. Koonsaeng, E. Traversa, and A. Laobuthee, "Electrolyte materials for solid oxide fuel cells derived from metal complexes: Gadoliniadoped ceria," Ceramics International, vol. 38, no. 3, pp. 24032409, 2012.

[24] W. Wattanathana, C. Veranitisagul, S. Wannapaiboon, W. Klysubun, N. Koonsaeng, and A. Laobuthee, "Samarium doped ceria (SDC) synthesized by a metal triethanolamine complex decomposition method: Characterization and an ionic conductivity study," Ceramics International, vol. 43, no. 13, pp. 98239830, 2017.

[25] C. Veranitisagul, A. Kaewvilai, S. Sangngern et al., "Novel recovery of nano-structured ceria $\left(\mathrm{CeO}_{2}\right)$ from $\mathrm{Ce}(\mathrm{III})$-benzoxazine dimer complexes via thermal decomposition," International Journal of Molecular Sciences, vol. 12, no. 7, pp. 4365-4377, 2011.

[26] D. Ciuparu, M. R. Lyubovsky, E. Altman, L. D. Pfefferle, and A. Datye, "Catalytic combustion of methane over palladium-based catalysts," Catalysis Reviews: Science and Engineering, vol. 44, no. 4, pp. 593-649, 2002.

[27] T. M. Onn, S. Zhang, L. Arroyo-Ramirez et al., "Improved thermal stability and methane-oxidation activity of $\mathrm{Pd} / \mathrm{Al}_{2} \mathrm{O}_{3}$ catalysts by atomic layer deposition of $\mathrm{ZrO}_{2}$," ACS Catalysis, vol. 5, no. 10, pp. 5696-5701, 2015.

[28] P. Gélin and M. Primet, "Complete oxidation of methane at low temperature over noble metal based catalysts: a review, Applied Catalysis B: Environmental, vol. 39, no. 1, pp. 1-37, 2002.

[29] Y.-H. Chin, C. Buda, M. Neurock, and E. Iglesia, "Consequences of metal-oxide interconversion for $\mathrm{C}-\mathrm{H}$ bond activation during $\mathrm{CH}_{4}$ reactions on Pd catalysts," Journal of the American Chemical Society, vol. 135, no. 41, pp. 15425-15442, 2013.

[30] F. Yin, S. Ji, P. Wu, F. Zhao, and C. Li, "Deactivation behavior of Pd-based SBA-15 mesoporous silica catalysts for the catalytic combustion of methane," Journal of Catalysis, vol. 257, no. 1, pp. 108-116, 2008.

[31] N. M. Martin, M. Van den Bossche, A. Hellman et al., "Intrinsic ligand effect governing the catalytic activity of Pd oxide thin films," ACS Catalysis, vol. 4, no. 10, pp. 3330-3334, 2014.

[32] N. Yang, J. Liu, Y. Sun, and Y. Zhu, “Au@PdO $\mathrm{Pd}_{\mathrm{x}}$ with a $\mathrm{PdO}_{\mathrm{x}}{ }^{-}$ rich shell and Au-rich core embedded in $\mathrm{Co}_{3} \mathrm{O}_{4}$ nanorods for catalytic combustion of methane," Nanoscale, vol. 9, no. 6, pp. 2123-2128, 2017. 

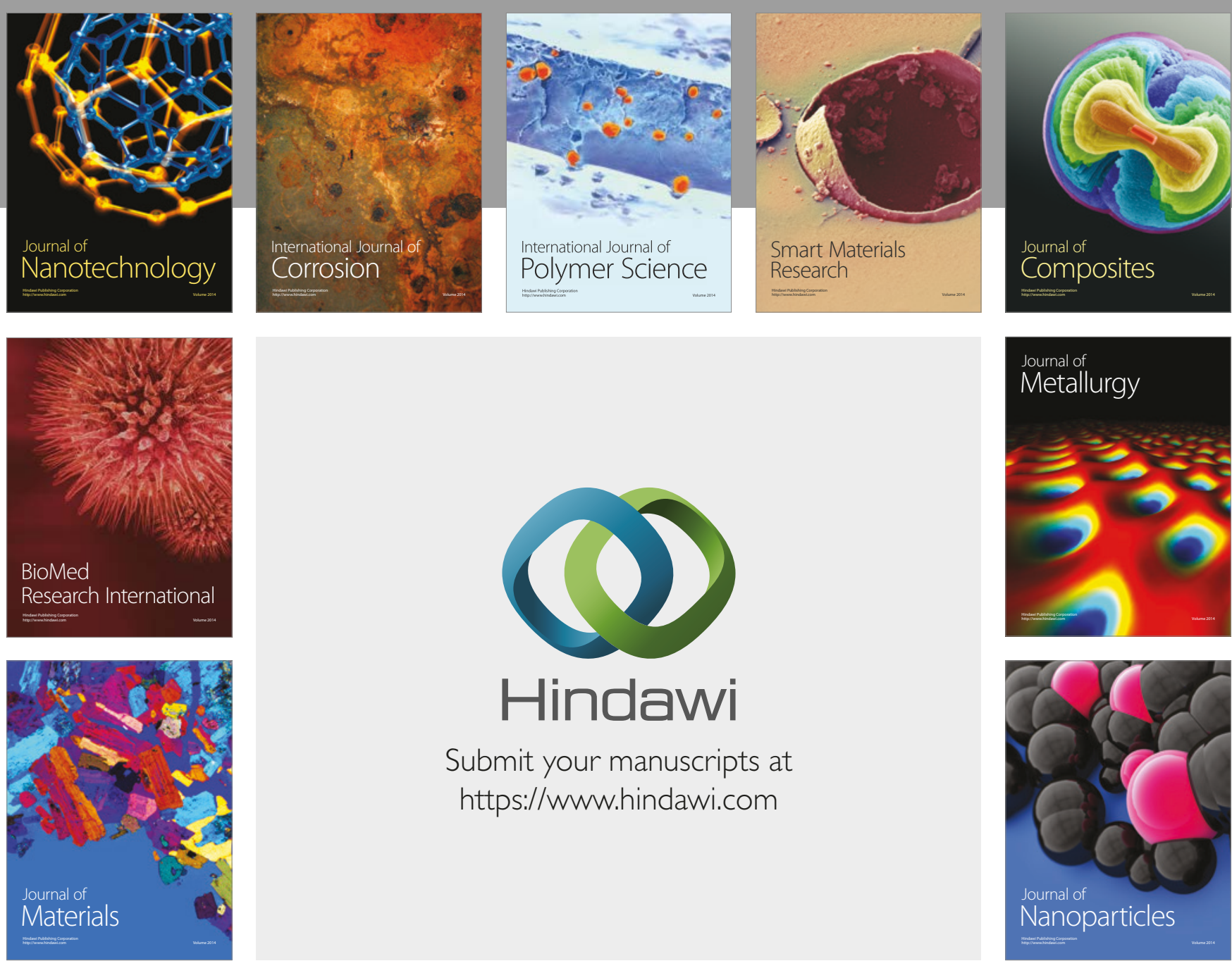

\section{Hindawi}

Submit your manuscripts at

https://www.hindawi.com
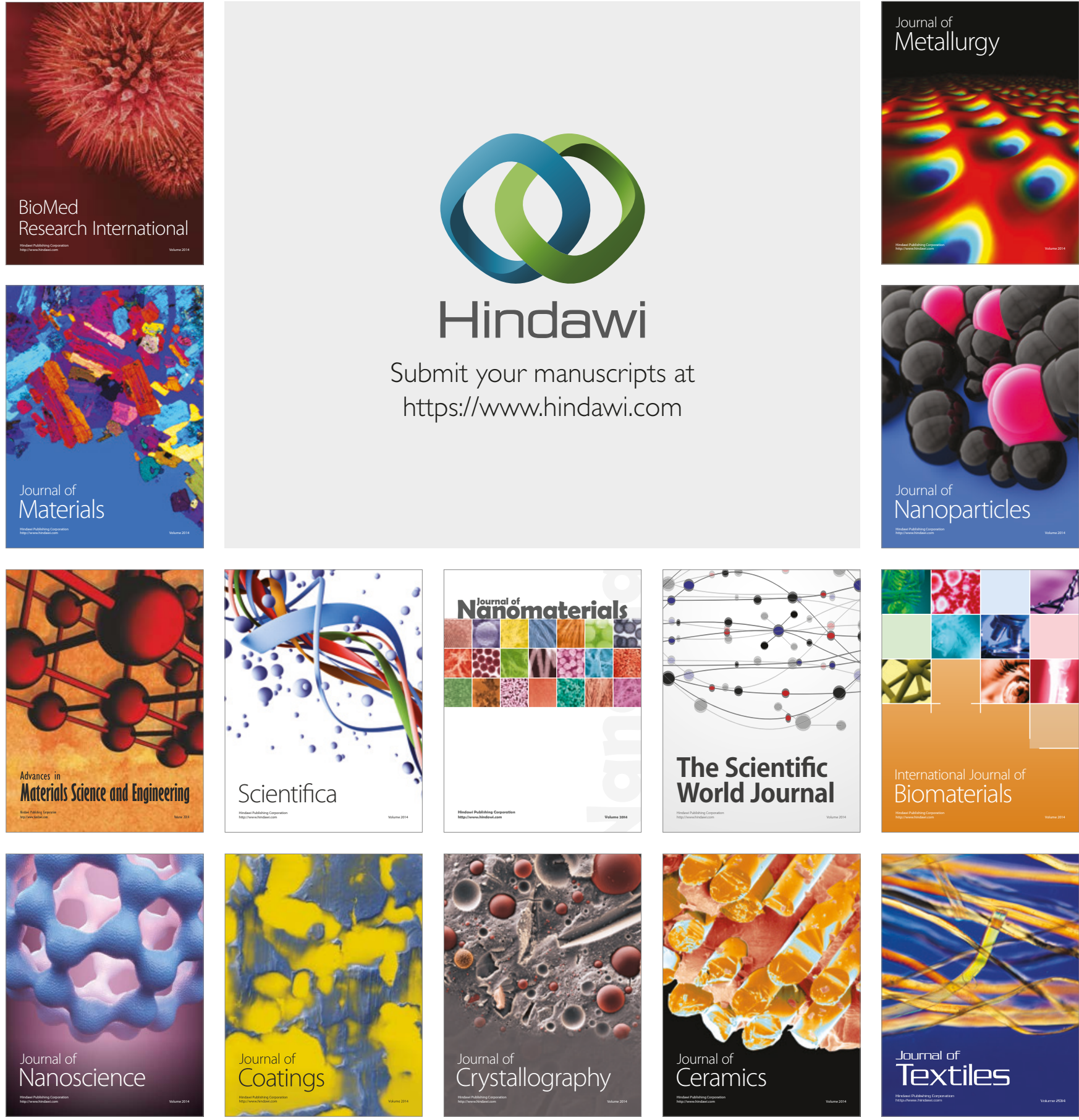

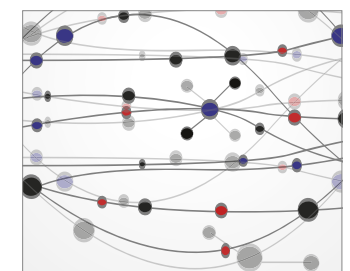

The Scientific World Journal
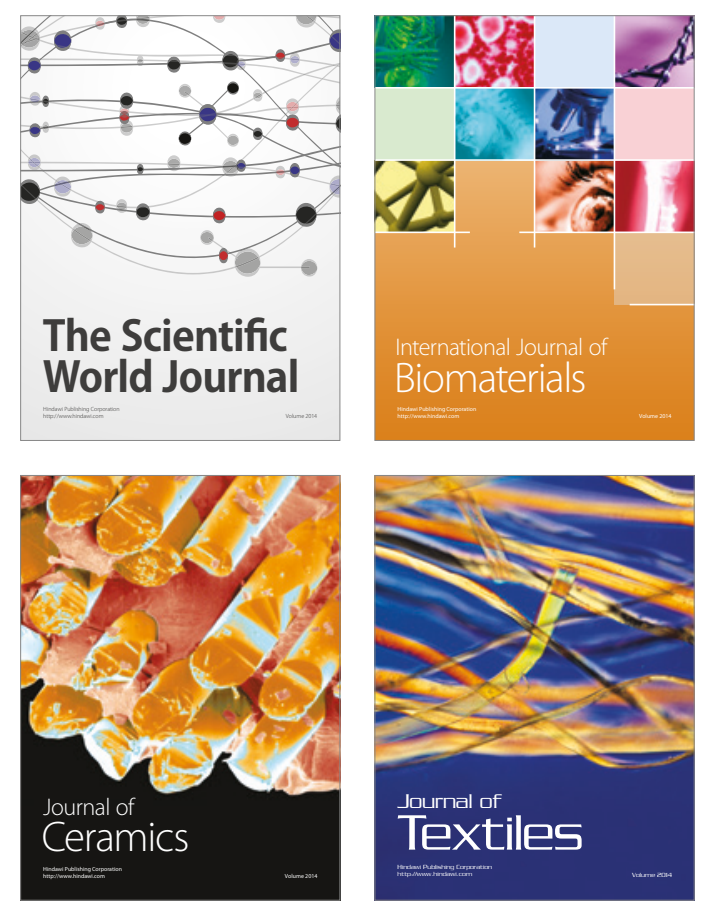